\title{
PENANAMAN KARAKTER ISLAMI BERBASIS SCHOOL BRANDING DI SMPN 3 SLAHUNG PONOROGO
}

\author{
Evin Fatma Fidhiyanti' ${ }^{1}$ Katni $^{2}$, Nurul Abidin ${ }^{3}$ \\ Universitas Muhammadiyah Ponorogo \\ 1evinriyanto@gmail.com, ${ }^{2}$ katni2459@gmail.com, ${ }^{3}$ nurulabidin@umpo.ac.id
}

\begin{abstract}
Abstrak
Temuan penelitian ini adalah (1) Strategi Penanaman Karakter Islami berbasis School branding di SMPN 3 Slahung Ponorogo adalah melalui nilai religius dan lingkungan adiwiyata. Nilai religius terdiri dari 2 pokok yang pertama kegiatan ibadah dan kedua akhlak. Displin diri dibagi menjadi 4 yaitu disiplin masuk sekolah, disiplin mengikuti pelajaran, displin berpakaian, dan displin bergaul. Sedangkan Lingkungan adiwiyata melalui kegiatan pengelolaan sampah, pengelolaan air limbah, pengelolaan green house, dan pengelolaan kebun buah. School branding adalah memberdayakan lingkungan sekitar menjadi lingkungan adiwiyata serta dalam publikasi kegiatan dan program yang menonjol melalui media elektronik seperti blog, facebook dan koran. Faktor pendukung dan faktor penghambat Penanaman Karakter Islami berbasis School branding di SMPN 3 Slahung Ponorogo adalah faktor pendukung meliputi adanya buku-buku agama, adanya sarana tempat ibadah yang memadai, adanya kegiatan keagamaan, partisipasi yang kompak oleh warga sekolah, dan SMPN 3 Slahung sebagai sekolah yang mampu melakukan school branding dengan sekolah yang religius dan lingkungan adiwiyata. Sedangkan faktor penghambat meliputi waktu yang kurang memadai, kurangnya ilmu keagamaan siswa, dan siswa kurang terbimbingnya agama di rumah dan di masyarakat.
\end{abstract}

Kata Kunci: Karakter, School Branding, Religiousitas, Adiwiyata 


\section{PENDAHULUAN}

Sekolah adalah tempat dimana anak mendapatkan pendidikan serta pengetahuan umum, agama, dan ilmu lainnya yang bermanfaat. Sekolah ada sebagai penunjang dan pendukung keluarga untuk tercapainya tujuan pedidikan. Ada juga berbagai masalah yang harus diperhatikan dalam prosesnya. Masalah yang ada dalam dunia pendidikan ialah masalah masa depan manusia. Sedangkan pendidikan agama harus ditanamkan sejak dini pada anak. Penanaman serta pembinaan keagamaan harus bersumber pada alQur'an dan al-Hadits, karena keduanya ialah sumber pandangan hidup umat Islam yang paling benar. Penanaman nilai-nilai adalah suatu kegiatan menanamkan tipe kepercayaan dalam sebuah sistem kepercayaan dimana seseorang berperilaku menghindari suatu tindakan, atau mengenai sesuatu yang pantas atau tidak pantas dikerjakan. (Thoha, 1996: 61). Sedangkan penanaman nilai-nilai pendidikan Islam ialah suatu kegiatan untuk menanamkan suatu kepercayaan untuk mengamalkan kebaikan dan menjauhi keburukan dalam kehidupan sehari-hari menurut syariat Islam.

Lembaga pendidikan di ciptakan untuk mengantarkan peserta didik dalam meningkatkan perilaku yang positif, salah satu usaha yang dilakukan dengan manajemen pengelolaan pendidikan dengan baik, arah pekerjaan yang jelas, landasan yang mantap, dan cara-cara mendapatkan yang transparan. Dengan demikian, manajeman dalam arti mengatur segala sesuatu agar dilakukan dengan baik, tepat dan tuntas merupakan hal yang harus dilakukan untuk mengantarkan pserta didik mencapai manusia yang seutuhnya (Saputro, 2015).

Sekolah Menengah Pertama Negeri 3 Slahung Ponorogo merupakan salah satu sekolah yang berlokasi di kecamatan Slahung yang beralamatkan di Jl. Beji Agung, RT/RW 1/3, Dusun. Tlogo, Desa Duri, Kecamatan Slahung, Kabupaten Ponorogo, Propinsi Jawa Timur. Secara geografis terletak di baratdaya dari pusat kota Ponorogo yang berjarak $25 \mathrm{~km}$. Sekolah Menengah Pertama Negeri 3 Slahung Ponorogo yang selanjutnya disingkat SMPN 3 Slahung Ponorogo memiliki peserta didik sebanyak 131 terdiri dari 77 laki-laki dan 54 perempuan yang dibagi menjadi 6 rombongan belajar. Pada tahun ajaran 2017/2018 menerapkan kurikulum 2013.

Dalam proses pembelajaran, siswa harus didorong untuk menyampaikan dan menyanggah pendapat, mengidentifikasi dan mengklarifikasi masalah, serta menanggapi dan menyajikan berbagai solusi atas permasalahan yang dihadapi. Tidak kalah penting, guru juga harus memahami bagaimana cara menerapkan metode pengajaran konstruktif yang sesuai karakteristik siswa (Irwanto et al., 2018). Kurikulum 2013 adalah suatu model kurikulum yang dapat mengintegritaskan nilai-nilai afektif, kognitif dan psikomotor dari beberapa pelajaran yang berkaitan satu dengan yang lainnya. SMPN 3 Slahung Ponorogo ini juga mempunyai school 
branding yaitu religious, karakter, dan adiwiyata. Menurut Swasty, Branding dimaknai sebagai permerekan. Pemaknaan ini diambil dari kata dasar branding yaitu brand. Maksudnya branding adalah upaya untuk memberikan suatu arti merek sehingga berbeda dengan merek yang lain. Simpelnya, makna branding adalah sebuah proses menyeluruh mulai dari pemilihan unsur-unsur, nilai-nilai sampai janji-janji yang diberikan sebuah merek (barang, jasa, perusahaan dan sebagainya) sehingga memiliki perbedaan dengan brand lain. (Swasty, 2016: 14)

School Branding merupakan sebuah upaya memberikan brand kepada sekolah sebagai bentuk jasa dengan janji-janji dan nilai-nilai (positioning) yang berbeda dengan sekolah lain (diferensiasi) untuk mempengaruhi orang lain (strategi) agar memilih lembaga pendidikan/sekolah tertentu.

Tentunya school branding yang sudah melekat di SMPN 3 Slahung Ponorogo bukan sekedar nama tapi juga terbukti dengan adanya penerapanpenerapan nyata di sekolah. School branding ini adalah cara dimana peserta didik di Sekolah Menegah Pertama Negeri 3 Slahung Ponorogo dapat menerapkan beberapa bentuk penanaman nilai-nilai pendidikan Islam yang juga berperan penting dalam melakukan kegiatan sehari-hari. Selain school branding, SMPN 3 Slahung Ponorogo juga disebut sekolah adiwiyata.

Berdasarkan studi pendahuluan penanaman nilai-nilai pendidikan Islam (religius) di SMPN 3 Slahung Ponorogo melalui berbagai cara yang unik. Sebuah metode yang sesuai dan efektif diharapkan mampu memberikan suatu pola pendidikan praktis yang baik dan bermanfaat. Pola pendidikan yang dimaksud adalah pendidikan yang menekakankan pada perilaku sosial peserta didik dengan menguatkan pada sisi nilai islami, maka dengan adanya penanaman nilai-nilai Islam pada peserta didik diharapkan akan mampu memberikan perubahan pada perilaku peserta didik menuju yang lebih baik seperti lebih disiplin dalam segala aturan yang dibuat di sekolah maupun disiplin dalam beragama serta disiplin dalam segala hal, lebih betanggungjawab atas segala amanah yang diberikan, lebih khusu' dalam beribadah, prestasi lebih banyak diraih dalam segala bidang dan mampu memberikan citra positif pada masyarakat.

Tujuan penelitian ini adalah untuk mendeskripsikan strategi penanaman karakter islami berbasis School branding di SMPN 3 Slahung Ponorogo dan untuk mendeskripsikan hasil penanaman karakter islami berbasis School branding di Sekolah Menengah Pertama Negeri 3 Slahung Ponorogo.

Pendidikan karakter islami adalah upaya-upaya untuk penanaman kecerdasan kepada anak dalam berpikir, bersikap, dan berperilaku sesuai nilai-nilai luhur islami yang menjadi jati diri seseorang. (Purwati, dkk, 2014 : $5)$. 
Strategi penanaman karakter islami melalui karakter religius, jujur, toleransi, disiplin, kerja keras, kreatif, mandiri, demokratis, rasa ingin tahu, semangat kebangsaan, cinta tanah air, menghargai prestasi, cinta damai, dan peduli sosial.(Kurniawan, 2017 : 127-158). Sedangkan Adiwiyata adalah tempat yang baik dan ideal untuk mendapatkan, memperoleh, dan mendalami ilmu pengetahuan, norma dan etika yang dapat menjadi dasar manusia menuju terciptanya kesejahteraan hidup dan menuju kepada cita-cita pengembangan berkelanjutan. (Dewi, dkk, $2007: 4-5$ ).

Kegiatan Untuk membentuk atau meningkatkan brand image sekolah, peran hubungan masyarakat (humas) sangat berpengaruh penting untuk dijadikan perantara membangun citra positif sekolah, selain itu fungsi humas juga menjadi media marketing pendidikan, media sosialisasi sekolah kepada masyarakat umum dan menambah wawasan publik tentang sekolah. (Laili, dkk, 2015)

Nilai adalah suatu perangkat keyakinan dan perasaan yang dirasa sebagai identitas atau ciri khas pada pemikiran, perasaan, kriteria dan perilaku seseorang. (Daradjat, $1996: 59$ ).

Nilai adalah sesuatu yang tidak berwujud, ideal, nilai juga bukan benda konkrit, bukan fakta, tidak hanya persoalan benar dan salah yang menuntut pembuktian empirik, melainkan sosial penghayatan yang dikehendaki, disenangi, dan tidak disenangi. ( Isna, 2007 : 98). Nilai adalah sesuatu yang mampu membuat manusia lebih sempurna sesuai dengan hakikatnya dan sangat penting juga berguna bagi manusia. Nilai adalah suatu mutu atau penghargaan terhadap sesuatu, yang dapat menjadi dasar untuk menentukan tingkah laku seseorang. (Daroeso, 1986 : 20).

Pendidikan Islam adalah suatu bimbingan terhadap pertumbuhan jasmani dan rohani manusia menurut ajaran Islam yang bertujuan mengarahkan, mengajarkan, melatih, mengasuh dan mengawasi berlakunya semuanya ajaran Islam. (Arifin, 1987: 13-14).

Pendidikan agama meliputi berbagai bidang studi, sebagaimana yang ditetapkan jenis dan tingkat pendidikan yaitu al-Qur'an, hadist, akidah, ibadah, sejarah, akhlak, dan pengetahuan lainnya. (Ahmad, 2008 : 71).

Sedangkan karakter secara bahasa berasal dari bahasa latin "character", yang berarti watak, tabiat, sifat-sifat kejiwaan, budi pekerti, kepribadian, atau akhlak. Secara istilah karakter adalah sifat manusia yang tergantung dari faktor kehidupannya sendiri. ( Depdiknas, 2008 : 219). Karakter adalah suatu proses pembudayaan dan pemberdayaan nilai-nilai luhur dalam lingkungan sekolah, keluarga, dan masyarakat. (Koentjaraningrat, $2002: 29$ ).

Menanamkan nilai-nilai religius memerlukan kerjasama yang baik antara guru sebagai tim pengajar dengan pihak-pihak luar yang terkait. Nilainilai religius ini dapat diajarkan kepada peserta didik melalui beberapa 
kegiatan religius. Kegiatan religius memberikan dampak positif pada pembiasaan berperilaku religius. Diharapkan peserta didik untuk selalu bertindak sesuai moral dan etika. (Suseno, 2000: 14-17). Kegiatan religius dapat diajarkan sebagai pembiasaan diantara lain: Berdoa atau bersyukur. Berdoa adalah ungkapan syukur secara langsung kepada Allah Swt. Melaksanakan kegiatan di masjid seperti sholat dhuhur berjamaah, belajar baca tulis al-Qur'an, dan sholat jum'at berjamaah. Merayakan hari raya keagamaan seperti hari raya Idul Adha, peserta didik dapat melakukan sholat id bersama selanjutnya memotong hewan qurban dan membagi langsung kepada orang yang berhak. Isra' mi'raj, pengajian. Hari raya Idul Fitri, kegiatan sholat id bersama selanjutnya bersilaturahmi ke rumah guru. Mengadakan kegiatan keagamaan seperti mabit (bermalam), pondok ramadhan.

Selanjutnya Adiwiyata berasal dari bahasa Sansekerta yaitu Adi dan Wiyata, Adi adalah besar, agung, baik, ideal atau sempurna. Wiyata adalah tempat untuk mendapatkan, memperoleh, dan mendalami ilmu pengetahuan, norma dan etika dalam berkehidupan sosial. Pendidikan untuk meningkatkan pengetahuan dan pemahaman lingkungan hidup kepada peserta didik dan masyarakat, maka pada tanggal 3 Juni 2005 telah ditandatangani Kesepakatan Bersama antara Menteri Negara Lingkungan Hidup dengan Menteri Pendidikan Nasional. Realisasi dari kesepakatan tersebut, pada tanggal 21 Pebruari 2006 telah dicanangkan Program Adiwiyata, yaitu sekolah peduli dan berbudaya lingkungan. Program adiwiyata digagas untuk membentuk dan mendorong sekolah di Indonesia agar turut serta melaksanakan segala upaya pemerintah memajukan pelestarian lingkungan dan pembangunan berkelanjutan untuk kepentingan generasi masa depan. Program Adiwiyata adalah program yang digagas oleh Kementerian Negara Lingkungan Hidup dalam rangka mendorong terciptanya pengetahuan dan kesadaran warga sekolah dalam upaya pelestarian lingkungan hidup. Dalam program ini diharapkan agar setiap warga sekolah ikut terlibat dalam kegiatan sekolah menuju lingkungan yang sehat dan menghindari dampak lingkungan yang negatif. Tujuan program Adiwiyata adalah menciptakan kondisi lingkungan yang baik bagi sekolah untuk menjadi tempat pembelajaran dan menumbuhkan kesadaran warga sekolah, sehingga di masa yang akan datang warga sekolah dapat turut bertanggungjawab dalam upaya-upaya penyelamatan lingkungan hidup dan pembangunan berkelanjutan.

Kegiatan utama Program Adiwiyata adalah mewujudkan kelembagaan sekolah yang peduli dan berbudaya lingkungan bagi sekolah di Indonesia. Adapun nilai-nilai karakter dari program adiwiyata ini meliputi kebersamaan, keterbukaan, kejujuran, keadilan dan kelestarian fungsi lingkungan hidup, serta sumber daya alam. (Dewi, dkk, 2007 :5-6). 
Kegiatan peduli lingkungan meliputi: (a) Pembiasaan memelihara kebersihan dan kelestarian lingkungan sekolah; (b) Tersedia teempat pembuangan sampah dan tempat cuci tangan; (c) Menyediakan kamar mandi dan air bersih; (d) Pembiasaan hemat energy; (e) Membuat biopori di sekolah (f) Membangun saluran pembuangan air limbah dengan baik; (g) Melakukan pembiasaan memisahkan jenis sampah organik dan non organic. (h). Penugasan pembuatan kompos dari sampah organic. (i) Menyediakan peralatan kebersihan; (j) Memrogramkan cinta bersih lingkungan.

\section{PEMBAHASAN}

1. Strategi Penanaman Karakter Islami Berbasis School branding di SMPN 3 Slahung Ponorogo.

Strategi yang dilakukan dalam penanaman karakter islami berbasis school branding di SMPN 3 Slahung Ponorogo yaitu melalui penanaman nilai Religius, yang meliputi: Ibadah dibagi menjadi 3 kegiatan wajib yang diterapkan yaitu sholat Dhuha berjamaah, sholat Dhuhur berjamaah, dan sholat Jum'at di sekolah. Sholat Dhuha dilakukan berjamaah dengan imam guru dan makmum peserta didik laki-laki maupun perempuan. Pelaksanaan sholat dhuha berjamaah pada saat jam istirahat pertama. Pada waktu sholat berlangsung bila ada peserta didik perempuan yang tidak sholat (berhalangan), maka mereka duduk di depan masjid dan tetap menunggu sampai sholat selesai. Ini adalah penerapan pendisiplinan yang sangat baik karena ada absensi untuk yang berhalangan sholat. Dengan penerapan ini tidak ada yang bisa membolos untuk mengikuti sholat Dhuha berjamaah. Tujuan adanya penerapan sholat Dhuha berjamaah di sekolah adalah agar peserta didik paham tata cara sholat Dhuha, sadar melasanakan, memahami manfaat sholat Dhuha, displin membagi waktu, dan dapat meningkatkan nilai ibadah peserta didik. Sedangkan Sholat Dhuhur dilakukan berjamaah dengan imam guru dan makmum peserta didik laki-laki maupun perempuan. Pelaksanaan sholat Dhuhur berjamaah biasanya pukul 12.00 sampai 12.30 karena setelah sholat Dhuhur berjamaah, peserta didik langsung pulang. Pada waktu sholat berlangsung bila ada peserta didik perempuan tidak sholat (berhalangan), maka mereka duduk di depan masjid dan tetap menunggu sampai sholat selesai. Ini adalah penerapan yang baik karena ada buku sholat sebagai evaluasi pendidiplinan peserta didik. Dengan adanya buku sholat ini tidak ada yang bisa membolos mengikuti sholat Dhuhur berjamaah. Tujuan adanya penerapan sholat Dhuhur berjamaah di sekolah adalah agar peserta didik paham tata cara sholat Dhuhur, displin shalat, disiplin membagi waktu, dan dapat meningkatkan iman dan takwa peserta didik kepada Allah Swt. Selanjutnya sholat jum'at dilakukan berjamaah dengan imam guru dan makmum peserta didik laki-laki. Sedangkan peserta didik perempuan 
mengaji di dalam kelas. Pelaksanaan sholat jum'at sekitar pukul 12.00 sampai 12.30. Tujuan adanya penerapan sholat jum'at di sekolah adalah agar peserta didik paham tata cara sholat Jum'at, paham dan sadar bahwa laki-laki wajib melaksanakan sholat jum'at, dapat menambah ilmu dengan adanaya khotbah, dan dapat meningkatkan iman peserta didik. Kegiatan tersebut merupakan strategi penanaman karakter religious pada aspek akidah, ibadah dan akhlak.

Sedangkan penanaman karakter islami tentang akhlak di SMPN 3 Slahung melalui disiplin diri dan hormat pada guru. Disiplin diri adalah hal-hal yang dapat mengatur segala sikap, tingkah laku penentu kegiatan yang akan dilakukan yaitu disiplin diri masuk sekolah bahwa setiap peserta didik antusias untuk masuk sekolah, ini dibuktikan dengan semangat peserta didik saat masuk sekolah. Penentu keaktifan peserta didik saat masuk sekolah adalah absensi kelas yang setiap hari diisi apakah peserta didik tersebut masuk, ijin, atau sakit. Disiplin diri mengikuti pelajaran bahwa dengan datangnya mereka ke sekolah berarti mereka sudah siap menerima ilmu-ilmu pelajaran yang diberikan oleh guru. Penentu dari keaktifan mengikuti pelajaran dilihat pada saat peserta didik melaksanakan ujian semester atau pada saat pengerjaan tugas. Setiap soal atau tugas akan dinilai dan akan terrekap pada saat peserta didik menerima hasil ujian (raport). Disiplin diri berpakaian atau berseragam, SMPN 3 Slahung tentunya mempunyai aturan pemakaian seragam setiap harinya sesuai dengan syari'at Islam. Pada hari senin dan selasa peserta didik memakai seragam atasan putih dan bawahan biru dongker, pada hari rabu dan kamis memakai seragam atasan warna pink dan bawahan warna putih dan hari jum'at dan sabtu memakai seragam pramuka. Semua pakaian mereka menutup aurot. Penentu kedisplinan berseragam terlihat pada saat peserta didik memakai seragam sesuai aturan dan memakai atribut pelengkap seragam. Disiplin diri bergaul, di masa SMP dimana peserta didik mulai mengenal perbedaan lawan jenis mereka. Di SMPN 3 Slahung peserta didik laki-laki dan perempuan duduk di kelas dengan barisan perempuan sendiri dan barisan bangku laki-laki sendiri. Bertujuan menghindari perilaku-perilaku negatif yang muncul pada saat jam pelajaran, dan melatih mereka untuk menghargai privasi masing-masing gender. Hormat pada guru adalah tata cara bersikap, berperilaku dan beradab kepada guru sebagai rasa hormat padanya yaitu dengan salam, ketika peserta didik bertemu atau datang masuk sekolah, pada saat itu juga guru sudah ada di depan gerbang untuk menyambut mereka, mereka diwajibkan memberi salam Assalamualakum $W r$ Wb kepada guru. Tujuannya adalah agar peserta didik terbiasa mengucapkan salam saat dimanapun mereka berada. Salim, setelah mengucapkan salam peserta didik juga wajib salim (berjabat tangan dengan mencium tangan guru). 
Tujuannya adalah supaya peserta didik dapat menghormati dan terbiasa menghormati orang yang lebih tua atau gurunya. Senyum sapa, dengan tersenyum, maka orang yang kita beri senyuman akan merasa senang melihat kita, begitupun pada saat bertemu guru, maka senyum adalah hal yang penting untuk dilakukan. Menyapa guru dengan lembut dan dengan tutur bahasa yang baik, maka guru akan merasa tersanjung dan melihat akhlak baik dari peserta didik. Sopan santun, kebiasaan yang luar biasa diterapkan oleh SMPN 3 Slahung adalah pada saat peserta didik masuk gerbang sekolah, mereka yang menaiki sepeda, turun dan menuntun sepedanya sampai parkir, jika mereka menaiki sepeda motor, maka sepeda motor dimatikan dan menuntunnya sampai parkir. Kebiasaan luar biasa ini sudah diterapkan dan berhasil sampai sekarang. Tujuannya adalah peserta didik memiliki rasa hormat dan dapat menciptakan rasa tenang tanpa suara berisik dari mesin motor atau sepeda.

Sedangkan dalam menciptakan lingkungan adiwiyata, SMPN 3 Slahung Ponorogo melakukan pengelolaan sampah, dengan beberapa tahapan dimana sampah-sampah yang menumpuk akan menjadi berguna dan bermanfaat. Adapun langkah memprosesnya adalah sampah dipilah menjadi 3 yaitu sampah organik, sampah an organik, dan sampah berbahaya. Setelah proses pemilahan sampah hal yang harus dilakukan adalah proses pengolahan sampah. Karena SMPN 3 Slahung sudah mempunyai alat yang cukup lengkap untuk mengolah sampah organic, maka sampah organik diproses untuk dimanfaatkan menjadi pupuk kompos atau pupuk organik dan dipacking dengan rapi untuk memupuk tanaman di lingkungan sekolah, jika sisa akan dijual, sampah anorganik akan dimanfaatkan menjadi ketrampilan yang dapat dipajang di kelas masing-masing, dan sampah berbahaya akan di tanam dalam tanah.

Tujuannya adalah agar peserta didik mampu mengelola sampah dengan baik dan benar, dan dapat mendaur ulang sampah menjadi barang yang bermanfaat. Pengelolan green house, green house adalah wadah pembibitan dan pengembangbiakan tanaman untuk ditanam di lingkungan sekolah. Dengan adanya green house, maka tanaman dapat dirawat dengan baik serta tanaman terjaga dan tumbuh dengan subur. Setelah tanaman siap ditanam, maka tanaman tersebut dikeluarkan dari green house dan siap ditanam di lingkungan sekolah. Jadi tanaman-tanaman yang ada di lingkungan sekolah adalah hasil dari pengelolaan green house. Tujuannya adalah agar peserta didik mampu merawat dan mengembangbiakkan tanaman untuk dijadikan hiasan di taman atau menjadi sumber inspirasi usaha untuk pendapatan budidaya tanaman kelak ketika dewasa nanti. Pengelolaan air limbah, berupa hemat air, maka air limbah wudhu (air bekas wudhu) warga sekolah ditampung dalam kolam, kolam tersebut berisi ikan-ikan kecil dan dikembangbiakkan juga. Serta air limbah wudhu 
juga untuk menyirami tanaman di lingkungan sekolah. Jadi air wudhu tidak terbuang sia-sia dan dapat dimanfaatkan dengan baik. Itu semua tidak terlepas dengan adanya kolam penampung yang cukup besar dan luas yang dimiliki oleh SMPN 3 Slahung Ponorogo. Tujuannya adalah agar peserta didik mampu merawat ikan atau hewan lainnya dan menjadi sumber pendapatan sekolah serta sebagai latihan budidaya yang bermanfaat bagi kehidupan siswa untuk mencari nafkah.

Kegiatan pengelolaan kebun buah, dikarenakan SMPN 3 Slahung termasuk dataran tinggi, maka buah-buah dapat dikembangbiakkan dengan mudah. Tujuannya adalah agar peserta didik mampu belajar menanam dan merawat buah dan dapat menghasilkan uang hasil dari berkebun.

Menurut Ferdiana Nur Laili penciptaan brand image melalui kualitas atau mutu sekolah yang harus jelas dan nyata, dapat dipercaya atau diandalkan oleh pengguna atau customer yaitu wali murid dan masyarakat sekitar, kegunaan atau manfaat kegiatan jelas dan menghasilkan prestasi, meningkat pelayanan, harus siap resiko apapun dari setiap tindakan, dan harga membawa kualitas. Sesuai uraian teori tersebut SMPN 3 Slahung memberdayakan lingkungan sekitar menjadi lingkungan adiwiyata sehingga setiap yang datang ke sekolah baik siswa, wali murid, dan masyarakat merasakan lingkungan yang nyaman, bersih, sehat, sejuk dan rindang. Serta dalam publikasi kegiatan dan program yang menojol melalui berbagai pertemuan, kajian dan media elektronik seperti blog, facebook tentunya yang dikelola SMPN 3 Slahung dan juga media cetak yaitu koran.

2. Hasil Penanaman Karakter Islami berbasis School branding di SMPN 3 Slahung Ponorogo.

Hasil penanaman karakter islami berbasis school branding di SMPN 3 Slahung Ponorogo adalah Peserta didik disiplin dalam beribadah sebagai wujud manusia yang taat kepada Allah Swt. mematuhi perintahNya dan menjauhi laranganNya, maka peserta didik sudah terbiasa melaksanakan ibadah yaitu sholat Fardlu, Shalat Nafilah. Untuk itu peserta didik di SMPN 3 Slahung Ponorogo diajarkan sholat wajib maupun sholat Sunnah (nafilah) dilaksanakan di sekolah. Agar peserta didik dapat mandiri dan melakukan sholat tanpa harus disuruh ketika dirumah dan dimanapun mereka berada. Peserta didik dapat melaksanakan sholat tepat waktu, untuk itu peserta didik di SMPN 3 Slahung Ponorogo diajarkan sholat wajib maupun sholat sunnah yang dilaksanakan di sekolah agar dapat dilaksanakan tepat waktu atau tidak mengulur waktu sholat. Peserta didik rutin melaksanakan sholat sunnah, untuk itu peserta didik di SMPN 3 Slahung Ponorogo diajarkan sholat Sunnah agar mereka sadar manfaat dari sholat Sunnah juga luar biasa dan sangat berpengaruh dalam kehidupannya. Sholat sunnah juga mempunyai fungsi masing-masing 
dalam pelaksanaannya. Peserta didik dapat meningkatkan iman dan taqwa kepada Allah Swt. Hal ini berdampak pada peserta didik disiplin masuk sekolah, bahwa menuntut ilmu itu wajib, maka peserta didik di SMPN 3 Slahung Ponorogo diwajibkan masuk sekolah dan bila berhalangan hadir harus dengan ijin yang jelas, sehingga mereka merasa sangat membutuhkan ilmu dan berusaha selalu masuk sekolah. Peserta didik dapat disiplin mengikuti pelajaran, ilmu yang didapat salah satu prosesnya adalah mengikuti pelajaran di dalam maupun di luar kelas, sehingga peserta didik di SMPN 3 Slahung Ponorogo wajib mengikuti kegiatan pembelajaran di dalam maupun di luar kelas. Peserta didik menaati jadwal pemakaian seragam di sekolah, seragam adalah salah satu identitas sekolah, maka peserta didik selalu mengikuti aturan jadwal seragam dan atributnya, sehingga mereka selalu berpakaian seragam rapi. Peserta didik dapat membentengi diri dalam bergaul dengan lawan jenis, bergaul dengan lawan jenis memang dibutuhkan untuk interaksi dalam proses pembelajaran, maka dari itu peserta didik di SMPN 3 Slahung Ponorogo mempunyai aturan dalam bergaul sesama maupun lawan jenisnya. Peserta didik dapat membiasakan diri untuk mengucapkan salam, maka dari itu peserta didik di SMPN 3 Slahung Ponorogo ditanamkan kebiasaan mengucapkan salam dengan teman sesamanya, dengan guru maupun dengan lainnya. Peserta didik dapat membiasakan diri untuk salim atau berjabat tangan, berjabat tangan dibiasakan untuk menjalin keakraban dengan sesamanya dan untuk menghormati yang lebih tua. Mereka dapat membiasakan diri untuk menyapa dan selalu tersenyum, senyum adalah hal yang paling mudah untuk memberikan kebahagian kepada orang lain, maka dari di SMPN 3 Slahung Ponorogo dibiasakan untuk selalu memberi senyum dan memberi sapaan kepada teman maupun kepada guru. Peserta didik dididik dapat membiasakan diri untuk bersikap sopan dan santun serta berbicara lemah lembut, dengan selalu bersikap sopan santun dan bicara lemah lembut dapat menghargai orang lain dan selalu beradab dengan baik dengan siapapun dan dimana pun. Peserta didik dapat mengelola sampah dengan baik, dengan ilmu mengelola sampah diberikan, maka diharapkan dapat mengaplikasikan ilmu tersebut di rumah maupun di lingkungan dan juga dapat menjadi salah satu peluang usaha yang dapat menguntungkan. Kegiatan mengelola kebun buah dengan baik, dengan ilmu mengelola kebun buah diberikan, maka diharapkan dapat mengaplikasikan ilmu tersebut di rumah maupun di lingkungan dan juga dapat menjadi salah satu peluang usaha yang dapat ditekuni sebagai sumber peghasilan. Kegiatan peserta didik mengelola green house dengan baik, dengan ilmu mengelola green house diberikan, maka diharapkan dapat mengaplikasikan ilmu tersebut di rumah maupun di lingkungan dan juga dapat menjadi salah satu peluang usaha. Kegiatan 
mengelola air limbah, dengan ilmu mengelola air limbah diberikan, maka diharapkan peserta didik di SMPN 3 Slahung Ponorogo dapat mengaplikasikan ilmu tersebut di rumah maupun di lingkungan, agar lingkungan bersih, terawat serta asri dan menjadi lingkungan nyaman dan layak dihuni.

3. Faktor pendukung dan faktor penghambat penerapan karakter islami berbasis school branding Di SMPN 3 Slahung Ponorogo.

Faktor pendukung, adalah faktor yang mempunyai sisi positif dalam keberhasilan suatu kegiatan atau kebijakan yang diterapkan. Faktor pendukung penerapan karakter islami berbasis school branding di SMPN 3 Slahung adalah Tersedianya buku-buku agama, sekolah menyediakan bukan hanya buku mata pelajaran agama tetapi buku kajian tentang agama, sehingga banyak referensi yang dapat dibaca dan dipelajari. Manfaatnya adalah mempermudah siswa untuk mendapat ilmu agama yang lebih banyak dan mengaplikasikan ilmu tersebut dalam kehidupan mereka sehari-hari. Tersedianya sarana tempat ibadah yang memadai, SMPN 3 Slahung Ponorogo mendirikan atau memfasilitasi sebuah masjid yang dapat menampung warga sekolah saat beribadah, sehingga pelaksanaan sholat dapat berjalan dengan baik dan khidmat. Manfaatnya adalah dapat melaksanakannya ibadah berjamaah dengan seluruh warga sekolah. Adanya kegiatan-kegiatan keagamaan yang sering dilakukan, SMPN 3 Slahung Ponorogo membuat kegiatan keagamaan sebanyakbanyaknya dapat melatih peserta didik untuk membiasakan melakukan kebaikan dimanapun mereka berada, bukan dilakukan hanya karena tuntutan dan adanya sanksi jadi murni dari hati mereka sendiri. Manfaatnya adalah kesadaran diri peserta didik melakukan kebaikan dan menyebarkan syiar agama. Adanya partisipasi yang kompak oleh warga sekolah, SMPN 3 Slahung Ponorogo mempunyai banyak stiackholder, dengan adanya komunikasi yang terjalin dengan baik akan berpengaruh hubungan lahir batin antar warga sekolah dan membangun branding sekolah. Manfaatnya adalah dapat saling menghargai job description masing-masing individu dan menjalin keakraban antar warga sekolah. SMPN 3 Slahung sebagai sekolah school branding, membawa pengaruh positif terhadap seluruh warga sekolah maupun masyarakat disekitar lingkungan sekolah dan kepercayaan bahwa SMPN 3 Slahung mampu mengemban amanah untuk mendidik dan melayani konsumennya dengan baik sebagai sekolah yang maju dan bermutu.

Berdasarkan gagasan mikro-budaya dapat disintesis itu budaya mikro terkait dengan individu sebagai dosen denganadat istiadat yang ada di lingkungan sekitarnya. Kebiasaan di sini adalah sangat tergantung dari berbagai macam felds termasuk sifat masing-masingorang di lingkungan 
sekitarnya. Kebiasaan di sini sangat bergantung pada banyak orang di lapangan, termasuk properti setiap orang di lingkungan.

Faktor penghambat, adalah faktor yang mempunyai sisi negatif dan dapat berpotensi kegagalan menghambat keberhasilan suatu kegiatan atau kebijakan yang diterapkan. Faktor penghambat penerapan karakter islami berbasis branding scholl di SMPN 3 Slahung Ponorogo adalah waktu yang kurang memadai, karena waktu belajar yang disediakan sekolah dari pukul 07.00 sampai pukul 13.00 maka waktu yang disediakan oleh pihak sekolah kurang dikarenakan banyaknya jam mata pelajaran dan jam ekstrakulikuler yang ditempuh oleh peserta didik. Kurangnya ilmu keagamaan siswa, dapat dari berbagai faktor yaitu dari lingkungan rumah maupun kurangnya juga keagamaan orangtua atau keluarga peserta didik. Sebuah keluarga adalah tempat yang paling penting dalam kehidupan seorang anak mendapatkan kasih sayang. Sebuah lingkungan adalah tempat dimana anak bersosialisasi, mendapat berbagai pengalaman hidup, sedangkan di sekolah anak mendapatkan ilmu pelajaran dari guru. Siswa kurang terbimbingnya agama di rumah dan di masyarakat. SMPN 3 Slahung Ponorogo mendapati faktor ini sebagai penghambat karena banyak keluarga yang broken home. Hal yang mempengaruhi keluarga yang tidak harmonis, salah satu orang tua atau bahkan orang tua pergi mencari nafkah di luar negeri, sehingga anak dirumah sendiri atau dengan nenek dan kakeknya sehingga kurang perhatian dan pengawasan maupun pendidikan orang tua.

\section{PENUTUP}

Berdasarkan hasil penelitian yang peneliti lakukan mengenai penanaman karakter islami berbasis school branding di SMPN 3 Slahung Ponorogo dapat disimpulkan bahwa:

1. Strategi penanaman karakter islami berbasis school branding di SMPN 3 Slahung melalui: (1) kegiatan yang bernilai religius yakni ibadah dan akhlak. Kegiatan ibadah berbasis masjid yang meliputi kegiatan rutin yang diterapkan di sekolah yaitu sholat dhuhur berjamaah setiap hari, sholat dhuha berjamaah setiap hari, dan sholat Jum'at. Sedangkan akhlak meliputi disiplin diri dan hormat pada guru. Displin diri dibagi menjadi 4 yaitu disiplin masuk sekolah, disiplin mengikuti pelajaran, displin berpakaian, dan displin bergaul. Hormat pada guru, menerapakan $5 \mathrm{~S}$ yaitu salam, salim (berjabat tangan), senyum dan sapa, dan sopan santun. Selanjutnya untuk school branding, maka kegiatan tersebut di publikasi melalui berbagai media baik berupa pertemuan, kajian maupun media elektronik seperti blog, facebook, dan kegiatan kemasyarakatan yang dikelola SMPN 3 Slahung dan juga media cetak yaitu koran. (2) Melalui lingkungan adiwiyata penanaman karakter islami tentang lingkungan 
adiwiyata di SMPN 3 Slahung dilakukan kegiatan pengelolaan sampah, pengelolaan air limbah, pengelolaan green house, dan pengelolaan kebun buah. Hal tersebut digunakan sebagai school branding yang menjadikan setiap yang datang ke sekolah baik siswa, wali murid, dan masyarakat merasakan lingkungan yang nyaman, bersih, sehat, sejuk dan rindang.

2. Hasil Penanaman Karakter Islami berbasis School branding di Sekolah Menengah Pertama Negeri 3 Slahung Ponorogo adalah peserta didik dapat disiplin dalam beribadah, dapat melaksanakan sholat tepat waktu, rutin melaksanakan sholat sunnah, dapat meningkatkan iman dan taqwa khususnya beribadah walaupun berada di sekolah, disiplin masuk sekolah, disiplin mengikuti pelajaran, selalu menaati jadwal pemakaian seragam di sekolah, dapat membentengi diri dalam bergaul dengan lawan jenis, dapat membiasakan diri untuk mengucapkan salam, salim (berjabat tangan), menyapa dan selalu tersenyum, bersikap sopan dan santun serta berbicara lemah lembut, dapat mengelola sampah dengan baik, mengelola kebun buah dengan baik, mengelola green house, dapat mengelola air limbah dengan baik.

3. Faktor pendukung penanaman karakter islami berbasis school branding di SMPN 3 Slahung Ponorogo adalah tersedianya buku-buku agama, tersedianya masjid yang memadai, adanya kegiatan keagamaan, dan partisipasi yang kompak oleh warga sekolah. Faktor penghambat Penanaman Karakter Islami berbasis School branding di SMPN 3 Slahung Ponorogo adalah kurangnya waktu dalam memaksimalkan kegiatan, kurangnya ilmu keagamaan siswa, dan siswa kurang terbimbingnya agama di rumah dan di masyarakat.

\section{DAFTAR PUSTAKA}

A.Michael Huberman, dan Matthew B. Miles. Analisis data kualitatif Terj. Tjejep Rohidi. Jakarta : UI Press, 1992.

Arifin, HM., Filsafat Pendidikan Islam, Jakarta: Bina Aksara, 1987.

Arikunto, Suharsimi. Prosedur Penelitian: Suatu Pendekatan Praktik. Jakarta: Rineka Cipta, 2010.

B. Miles, Matthew \& Huberman, A. Michael, Analisis data kualitatif Terj. Tjejep Rohidi, Jakarta : UI Press, 1992.

Daradjat, Zakiyah, Ilmu Jiwa Agama, Jakarta: Bulan Bintang, 1996.

Daroeso, Bambang, Dasar dan Konsep Pendidikan Moral Pancasila, Surabaya: Aneka Ilmu, 1986.

Departemen Pendidikan Nasional, Kamus BesarBahsa Indonesia, Jakarta: Pusat Bahasa Depdiknas, 2008 
Dewi, Jo kumala, dkk. Sekolah Peduli dan Berbudaya Lingkungan, Jakarta: Kantor Lingkungan Hidup Kabupaten Ponorogo, 2007.

Fauzan Almansur, dan M. Djunaidi Ghony. Metode Penelitian Kualitatif. Jogjakarta : Ar-Ruzz Media, 2017.

Ghony, M. Djunaidi dan Almansur, Fauzan Metode Penelitian Kualitatif, Jogjakarta : Ar-Ruzz Media, 2017.

Irwanto, Saputro, A. D., Rohaeti, E., \& Prodjosantoso, A. K. (2018). Promoting Critical Thinking and Problem Solving Skills of Preservice Elementary Teachers through Process-Oriented GuidedInquiry Learning (POGIL). International Journal of Instruction, 11(4), 777-794. https://doi.org/10.12973/iji.2018.11449a

Isna, Mansur, Diskursus Pendidikan Islam, Yogyakarta: Global Pustaka Utama, 2001.

Koentjaraningrat, Kebudayaan Mentalitas dan Pembangunan, Jakarta: Gramedia, 2002.

Kumala Dewi , Jo, dkk, Sekolah Peduli dan Berbudaya Lingkungan, Jakarta: Kantor Lingkungan Hidup Kabupaten Ponorogo, 2007.

Kurniawan, Syamsul. Pendidikan Karakter. Yogyakarta: Ar-Ruzz, 2017.

Nur Laili, Ferdiana, dkk, "Hubungan Antara Brand Image Dan Motivasi Dengan Keputusan Peserta Didik Memilih Sekolah Di SMA Negeri 1 Sidayu Kabupaten Gresik, ”Jurnal Ilmiah Universitas Bakrie. Vol 3, No 01 Februari 2015.

Purwati, Eni, dkk. Pendidikan Karakter (Menjadi Berkarakter MuslimMuslimah Indonesia. Surabaya: Kopertais IV Press, 2014.

Saputro, A.D., 2015. Implementasi Manajemen Mutu Terpadu Di

Sekolah/madrasah. Al-Idarah, 5(2).

Suryanto, tulus; rahmat, abdul. Path analysis organizational commitment and micro culture against leadership lecturer in higher education. AKADEMIKA: Jurnal Pemikiran Islam, [S.1.], v. 23, n. 1, p. 27-42, july 2018. ISSN $23562420 . \quad \underline{\text { http://e }}$ journal.metrouniv.ac.id/index.php/akademika/article/view/1127.

Thoha, Chabib. Kapita Selekta Pendidikan Islam. Yogyakarta: Pustaka Pelajar, 1996.

Qadir Ahmad, Muhammad, Metodologi Pengajaran Agama Islam, Jakarta: PT Rineka Cipta, 2008. 